\title{
Pharmacokinetics of Dasatinib
}

\author{
Jana Hoř́ínková, Martin Šíma, Ondřej Slanař \\ Institute of Pharmacology, First Faculty of Medicine, Charles University \\ and General University Hospital in Prague, Prague, Czech Republic
}

Received April 12, 2019; Accepted September 4, 2019.

Key words: Dasatinib - Pharmacokinetics - pH-dependent absorption - Drug interaction

\begin{abstract}
Tyrosine kinase inhibitors have recently become an essential tool in management of chronic myeloid leukaemia (CML). Dasatinib, a representative of those drugs, acts by inhibiting key proteins included in CML development, predominantly Bcr-Abl and Src. Its advantage is that it shows activity in many cases where other agents bring no improvement due to resistance. Pharmacokinetics of dasatinib has specific characteristics that may play an important role in achieving sufficient exposure in patients. Therefore, the key pharmacokinetic properties are summarized in this report. For example, dasatinib absorption is significantly influenced by gastric $\mathrm{pH}$ and its modulation can be a source of serious interactions, as well as simultaneous administration of drugs affecting cytochrome P450.
\end{abstract}

This study was supported by the Charles University Project Progres Q25 and a grant no. SVV 260373.

Mailing Address: Mgr. Jana Hořínková, Institute of Pharmacology, First Faculty of Medicine, Charles University and General University Hospital in Prague, Albertov 4, 12800 Prague 2, Czech Republic; Phone: +420 224968 035; Fax: +420 224968 149; e-mail: jana.horinkova@lf1.cuni.cz 


\section{Introduction}

Possibilities of chronic myeloid leukaemia (CML) therapy have recently been broadening as there are new agents with antitumor activity that can be used to treat this hematologic malignancy. Dasatinib belongs among small molecules inhibiting tyrosine kinases (Cohen, 2002).

The first reports on dasatinib (formerly BMS-354825) in literature reach to 2004 (Lombardo et al., 2004). Two years later, in 2006, it was approved by FDA and EMA (brand name Sprycel ${ }^{\circledR}$ ). Indications in adults include Philadelphia chromosomepositive chronic myeloid leukaemia $(\mathrm{Ph}+\mathrm{CML})$ in chronic phase and Philadelphia chromosome-positive acute lymphoblastic leukaemia ( $\mathrm{Ph}+\mathrm{ALL})$, it is also approved for treatment of $\mathrm{Ph}+\mathrm{CML}$ in chronic phase in paediatric patients (Bristol-Myers Squibb, 2017). Dasatinib shows its benefits in cases where imatinib $\left(G l e e v e{ }^{\circledR}\right.$, older tyrosine kinase inhibitor firstly approved by FDA in 2001) (Novartis, 2018) fails because of resistance and it has been reported that dasatinib has 325 -fold greater activity in inhibiting Bcr-Abl than imatinib (O'Hare et al., 2005). Studies in vitro as well as in vivo have shown that dasatinib inhibits the kinase activity of 14 out of 15 imatinib-resistant Bcr-Abl isoforms with the only one not responding mutant, T315I (Shah et al., 2004).

The way dasatinib acts against cancer cells is explained by inhibition of several proteins that have their role in cancer pathogenesis as they are employed in cell differentiation, proliferation and survival, most importantly Bcr-Abl, Src, c-kit and PDGFR $\beta$ (platelet-derived growth factor receptor $\beta$ ) (Ikeda et al., 1991; Szczylik et al., 1991; Thomas and Brugge, 1997; Lombardo et al., 2004; Yang et al., 2010).

In conducted studies, dasatinib showed variable pharmacokinetic profiles with high intra subject variability (Chandani et al., 2017). This is the reason why the aspects of dasatinib pharmacokinetics are being studied in this review.

\section{Physical/chemical properties}

Dasatinib is a white to off-white powder with melting point of 280 to $286^{\circ} \mathrm{C}$ (Bristol-Myers Squibb Pharmaceutical Research Institute, 2007). It is a lipophilic substance with partition coefficient $(\log P)$ between octanol and water 2.71, which means it is able to pass well through cell membranes (Minematsu and Giacomini, 2011).

As a monohydrate, it is insoluble in water $\left(0.008 \mathrm{mg} / \mathrm{ml}\right.$ at $\left.24 \pm 4{ }^{\circ} \mathrm{C}\right)$, slightly soluble in ethanol, methanol, polyethylene glycol 400 and propylene glycol and very slightly soluble in acetone and acetonitrile (USP definition). It is practically insoluble in corn oil (Bristol-Myers Squibb Pharmaceutical Research Institute, 2007).

Solubility in water is $\mathrm{pH}$ dependent. The anhydrous free drug has characteristics of a weak base which is a subject of dissociation when placed into water environment. Two basic ionization constants $\left(p K_{a}\right)$ were determined (6.8 and 3.1) and one weekly acidic $p K_{a}$ (10.9) (Bristol-Myers Squibb Pharmaceutical Institute, 2007). According to in vitro investigation, the solubility surpasses $0.690 \mathrm{mg} / \mathrm{ml}$ at $\mathrm{pH}$ values lower than 
4.0, whereas in higher values it rapidly decreases $(0.205 \mathrm{mg} / \mathrm{ml}$ at $\mathrm{pH} 4.28$ and less than $0.001 \mathrm{mg} / \mathrm{ml}$ at $\mathrm{pH}$ 6.99) (Eley et al., 2009).

Another study confirming those findings was performed at the temperature of $37^{\circ} \mathrm{C}$. The results show that the solubility of dasatinib was surprisingly high at $\mathrm{pH}$ approximately $1(49.6 \mathrm{mg} / \mathrm{ml})$, due to full protonation of both basic nitrogen atoms. As expected, the solubility drops down to $3.62 \mathrm{mg} / \mathrm{ml}$ at $\mathrm{pH} 3.64$ and it reaches only $1.40 \mathrm{mg} / \mathrm{ml}$ at $\mathrm{pH} 3.81$. At higher values dasatinib becomes practically insoluble (Lubach et al., 2013). This fact of $\mathrm{pH}$-dependent solubility plays an important role in absorption from gastrointestinal tract, as the $\mathrm{pH}$ values can range variously, and they can be influenced by other concomitantly using drugs.

\section{Pharmacokinetics of dasatinib}

Pharmacokinetic parameters of dasatinib are summarized in Table 1.

\section{Absorption}

After oral administration, dasatinib is quickly absorbed from gastrointestinal tract. Preclinical testing in various species (mice, rats, dogs and monkeys) showed that maximum plasma concentrations were most frequently reached within 0.6 to $2 \mathrm{~h}$

\section{Table 1 - Pharmacokinetic parameters of dasatinib in preclinical and clinical trials}

\begin{tabular}{|c|c|c|c|c|c|c|}
\hline \multirow{2}{*}{$\begin{array}{l}\text { Parameter } \\
T_{\max }(\mathrm{h})\end{array}$} & \multicolumn{3}{|c|}{ Preclinical data } & \multicolumn{3}{|c|}{ Clinical data } \\
\hline & $\begin{array}{c}0.6-2.0 \\
\text { (Kamath } \\
\text { et al., 2008) }\end{array}$ & $\begin{array}{c}1 \\
\text { (Luo et al., } \\
2006)\end{array}$ & $\begin{array}{c}2 \\
\text { (Lagas et } \\
\text { al., 2009) }\end{array}$ & $\begin{array}{c}1.0 \\
\text { (Aplenc } \\
\text { et al., 2011) }\end{array}$ & $\begin{array}{c}0.5 \\
\text { (Christopher } \\
\text { et al., 2008b) }\end{array}$ & $\begin{array}{c}1.0 \\
\text { (Takahashi } \\
\text { et al., 2011) }\end{array}$ \\
\hline$F(\%)$ & $\begin{array}{c}\text { 14-34 } \\
\text { (Kamath } \\
\text { et al., 2008) }\end{array}$ & $\begin{array}{c}45-51 \\
\text { (Luo et al., } \\
2006)\end{array}$ & - & - & - & - \\
\hline $\begin{array}{l}\text { Plasma } \\
\text { protein } \\
\text { binding (\%) }\end{array}$ & $\begin{array}{c}\text { 92-97 } \\
\text { (Kamath } \\
\text { et al., 2008) }\end{array}$ & - & - & $\begin{array}{c}94 \\
\text { (Kamath } \\
\text { et al., 2008) }\end{array}$ & - & - \\
\hline $\mathrm{V}_{\mathrm{ss}}(\mathrm{l} / \mathrm{kg})$ & $\begin{array}{c}\text { 3.5-6.3 } \\
\text { (Kamath } \\
\text { et al., 2008) }\end{array}$ & - & - & - & - & - \\
\hline $\mathrm{V}_{\mathrm{z}} / \mathrm{F}(\mathrm{I})$ & - & - & - & $\begin{array}{l}\text { 606-9113 } \\
\text { (Takahashi } \\
\text { et al., 2011) }\end{array}$ & $\begin{array}{c}\text { 600-9464 } \\
\text { (Demetri et } \\
\text { al., 2009) }\end{array}$ & - \\
\hline$t_{1 / 2}(h)$ & $\begin{array}{c}\text { 0.9-4.2 } \\
\text { (Kamath } \\
\text { et al., 2008) }\end{array}$ & - & - & $\begin{array}{c}\text { 1.9-3.6 } \\
\text { (Aplenc } \\
\text { et al., 2011) }\end{array}$ & $\begin{array}{c}3.6 \\
\text { (Christopher } \\
\text { et al., 2008b) }\end{array}$ & $\begin{array}{c}2.2-4.9 \\
\text { (Demetri } \\
\text { et al., 2009) }\end{array}$ \\
\hline
\end{tabular}

$T_{\max }$ - time to reach maximum plasma concentration; $\mathrm{F}$ - bioavailability; $\mathrm{V}_{\mathrm{ss}}$ - apparent volume of distribution at steady state; $V_{z} / F-$ apparent volume of distribution during terminal phase after non-iv administration; $t_{1 / 2}-$ half-life 
( $T_{\max }-$ time to reach maximum plasma concentration) (Luo et al., 2006; Kamath et al., 2008; Lagas et al., 2009). Clinical studies achieved similar results with $T_{\max } 0.5$ to $1.0 \mathrm{~h}$. Among subjects, substantial variability was observed with $T_{\max }$ values ranging from 0.28 up to $6.3 \mathrm{~h}$ (Christopher et al., 2008b; Aplenc et al., 2011; Takahashi et al., 2011; Bristol-Myers Squibb, 2017).

Bioavailability is known to be variable between subjects, too. First preclinical studies in mice showed bioavailability from 45 to $51 \%$ (Luo et al., 2006), whereas other experiments performed in various species led to values between 14 and 34\% (14\% and $17 \%$ mice, $27 \%$ rats, 34\% dogs, $15.2 \%$ monkeys) (Kamath et al., 2008). Bioavailability in humans was not determined because intravenous administration would be risky, but we know that interindividual variability in AUC (area under the curve) can range from 32 to $118 \%$ (Dai et al., 2008) and intraindividual variability from 40 to $50 \%$ (Chandani et al., 2017).

Experiments, where dasatinib was administered intraportally in rats suggest that first-pass metabolism does not have a significant effect on bioavailability, and it is therefore limited mostly by absorption (Kamath et al., 2008).

Absorption of dasatinib can be influenced by meal, which is taken with the medicine, although the change is not significant. After a single dose of $100 \mathrm{mg}$, the mean AUC was increased by $14 \%$ in subjects with high-fat meal (Bristol-Myers Squibb, 2017).

Another factor impacting dasatinib absorption is gastric $\mathrm{pH}$ likely due to alteration of the drug solubility as described above. Dasatinib dissolves better in low $\mathrm{pH}$ values, leading to higher amount of drug being absorbed into blood. Gastric $\mathrm{pH}$ can be modulated by many substances including medications such as $\mathrm{H}_{2}$-receptor antagonists (e.g. famotidine, ranitidine), antacids or proton pump inhibitors (e.g. omeprazole, lansoprazole, rabeprazole) which cause increased gastric $\mathrm{pH}$ (Pali-Scholl et al., 2010; Mylan Pharmaceuticals, 2011; AstraZeneca Pharmaceuticals, 2012). On the other hand, there are agents that are able to induce gastric acid secretion or by other mechanism decrease gastric $\mathrm{pH}$ such as pentagastrin or betaine $\mathrm{HCl}$ (Chu et al., 1999; Yago et al., 2013; Šíma et al., 2019).

Effect of pentagastrin $(0.25 \mathrm{mg} / \mathrm{kg}, \mathrm{sc})$ and famotidine $(10 \mathrm{mg} / \mathrm{kg}$, iv) on dasatinib absorption was investigated in a preclinical study in rats. Both substances were administered $2 \mathrm{~h}$ prior to dasatinib administration. Unexpectedly, pentagastrin led to a slight decrease in AUC (from $0.421 \mu \mathrm{g} \times \mathrm{h} / \mathrm{ml}$ in control group to $0.297 \mu \mathrm{g} \times \mathrm{h} / \mathrm{ml}$ ). That could have been caused by rapid onset of pentagastrin action and too early dosing $2 \mathrm{~h}$ before dasatinib since the measured gastric $\mathrm{pH}$ after pentagastrin administration was the same as in control group and thus it probably stayed without effect on dasatinib absorption. Famotidine had a significant impact with dasatinib AUC decrease to $0.094 \mu \mathrm{g} \times \mathrm{h} / \mathrm{ml}$ (Lubach et al., 2013).

There was another interaction study in dogs with famotidine $(40 \mathrm{mg}$, orally, $3 \mathrm{~h}$ prior to dasatinib), pentagastrin ( $6 \mu \mathrm{g} / \mathrm{kg}$, im, $30 \mathrm{~min}$ prior to dasatinib) and betaine $\mathrm{HCl}$ (750 mg, orally, either $5 \mathrm{~min}$, or 5 and 20 min prior to dasatinib), in which 
probably due to administration only 30 min before dasatinib, pentagastrin led to a doubling of dasatinib AUC (measured gastric $\mathrm{pH}$ was also lower than in control group). Two tablets of betaine $\mathrm{HCl}(1,500 \mathrm{mg}$ in total) had the same effect on absorption as pentagastrin while when dasatinib was given with famotidine and petagastrin the negative effect of famotidine was mitigated (Pang et al., 2013).

In humans, the influence of famotidine and antacids (Maalox ${ }^{\circledR}-$ aluminium/ magnesium hydroxides) was examined in a study where dasatinib (50 mg) was administered twice a day, famotidine (40 mg) was given $2 \mathrm{~h}$ after dasatinib (and therefore $10 \mathrm{~h}$ before another dose of dasatinib) and the antacid $(30 \mathrm{ml})$ was given firstly $2 \mathrm{~h}$ before and then at the same time as dasatinib. Although famotidine didn't change first dasatinib dose absorption, the next dasatinib dose $10 \mathrm{~h}$ after famotidine was absorbed significantly worse (mean AUC decreased from 136 to $40.2 \mathrm{ng} \times \mathrm{h} / \mathrm{ml}$ ). Concomitant use of antacid similarly decreased dasatinib exposure (mean AUC of $46.3 \mathrm{ng} \times \mathrm{h} / \mathrm{ml}$ ), however, when separated by $2 \mathrm{~h}$, absorption remained unaltered (Eley et al., 2009).

Decrease of dasatinib exposure was also confirmed in a study in which pharmacokinetic profiles of Japanese patients treated with or without $\mathrm{H}_{2}$-receptor antagonists (famotidine 20-40 mg/day, nizatidine $300 \mathrm{mg}$ /day) or proton pump inhibitors (lansoprazole $30 \mathrm{mg} /$ day) were analysed. Results were variable but acid suppressants caused decrease in the extent of dasatinib absorption (mean AUC decreased from 3.51 to $1.47 \mathrm{ng} \times \mathrm{h} / \mathrm{ml} / \mathrm{mg}$ ) (Takahashi et al., 2012).

The effect of famotidine on dasatinib absorption has been also indicated in a case report suggesting more than 3fold decrease in dasatinib exposure when given concomitantly (Matsuoka et al., 2012).

Another study conducted in humans receiving dasatinib $(100 \mathrm{mg})$ alone, with rabeprazole (20 $\mathrm{mg}$ twice a day) or altogether with betaine $\mathrm{HCl}(1,500 \mathrm{mg})$ confirmed that proton pump inhibitors have negative effect on dasatinib absorption. However, betaine $\mathrm{HCl}$ mitigated this interaction (Yago et al., 2014).

\section{Table 2 - The effect of gastric pH modulators on dasatinib AUC}

\begin{tabular}{ll}
\hline Comedication & AUC (\% of dasatinib monotherapy AUC) \\
\hline Pentagastrin & $\downarrow$ (71\%) (Lubach et al., 2013); $\uparrow(223 \%)$ (Pang et al., 2013) \\
Famotidine & $\downarrow$ (22\%) (Lubach et al., 2013); $\downarrow$ (39\%) (Eley et al., 2009) \\
Rabeprazole & $\downarrow(14.7 \%)$ (Yago et al., 2014) \\
Any H2RA or PPI & $\downarrow(42 \%)$ (Takahashi et al., 2012) \\
$750 \mathrm{mg}$ betaine HCl & $\approx(119 \%)$ (Pang et al., 2013) \\
$1,500 \mathrm{mg}$ betaine HCl & $\uparrow(229 \%)$ (Pang et al., 2013) \\
Famotidine $+750 \mathrm{mg}$ betaine $\mathrm{HCl}$ & $\approx(113 \%)$ (Pang et al., 2013) \\
Famotidine $+1,500 \mathrm{mg}$ betaine $\mathrm{HCl}$ & $\uparrow(149 \%)$ (Pang et al., 2013) \\
Rabeprazole $+1,500 \mathrm{mg}$ betaine $\mathrm{HCl}$ & $\approx(96 \%)$ (Yago et al., 2014) \\
Antacid (2 h prior to dasatinib) & $\approx(104 \%)$ (Eley et al., 2009) \\
Antacid (concomitantly with dasatinib) & $\downarrow(45 \%)$ (Eley et al., 2009) \\
\hline
\end{tabular}

AUC - area under the curve 
The effect of gastric $\mathrm{pH}$ modulators on bioavailability of dasatinib is summarized in Table 2.

To conclude, combination of dasatinib with acid suppressants is problematic due to decreased dasatinib bioavailability. If necessary, it is advisable to use antacids separated from dasatinib at least by $2 \mathrm{~h}$. A wish to increase dasatinib bioavailability lead to an attempt to synthesize a compound that could act like a dasatinib prodrug. Thus, a compound called JLTN was synthesized with oral bioavailability increase to $150 \%$ of the original value. However, no additional development of the compound has followed so far (Liu et al., 2013).

\section{Distribution}

When absorbed into blood, most of dasatinib molecules bind to serum proteins (>90\%). The volume of distribution is very high, suggesting that dasatinib distributes well from vascular system to other tissues. A preclinical study performed in various species came with mean $\mathrm{Vd}$ values ranging from 3.5 to $6.3 \mathrm{I} / \mathrm{kg}$ and human volume of distribution was predicted to be around $4.2 \mathrm{I} / \mathrm{kg}$ (using scaling by body weight) (Kamath et al., 2008). Later experiments in men confirmed high volume of distribution with mean values from 600 to $9,464 \mathrm{I}$ and with large variability. After repeated administration, dasatinib does not show any signs of accumulation in the body (Demetri et al., 2009; Takahashi et al., 2011).

In breast-feeding females, dasatinib, as a basic molecule, reaches high concentrations in milk. First estimations considering only passive diffusion predicted lacteal distribution to be rather mild. However, dasatinib is a substrate of BCRP (breast cancer resistance protein) and since this protein is also expressed in mammary gland, we can suppose that BCRP is employed in active transport to the milk (He et al., 2008).

Although dasatinib crosses placental barrier, foetal plasma concentrations reach lower values than those in maternal blood. Concentrations measured in foetal plasma, brain, kidneys and liver were similar, suggesting that distribution in foetus occurs mostly by passive diffusion without specific transporters, which may not be fully evolved yet (He et al., 2008).

\section{Elimination (metabolism and excretion)}

Dasatinib half-life was determined in four different species - mice, rats, dogs and monkeys. Mice exhibited the lowest value $(0.9 \mathrm{~h})$, the longest half-life was observed in dogs (4.2 h) (Kamath et al., 2008). Human half-life values based on three clinical studies range from 2.2 to $4.9 \mathrm{~h}$ (Christopher et al., 2008b; Demetri et al., 2009; Aplenc et al., 2011).

Dasatinib undergoes several routes of metabolism, particularly oxidative and conjugative. Hydroxylation, $\mathrm{N}$-dealkylation, $\mathrm{N}$-oxidation, alcohol oxidation and direct glucuronide or sulphate conjugation seem to be the most employed reactions, leading to formation of many metabolites of which nineteen have been identified. 
Dasatinib represents the major circulating moiety in a mass balance study, whereas metabolites are accountant for 40 to $60 \%$ of total radioactivity (Christopher et al., 2008a; Kamath et al., 2008).

Although the most abundant metabolite observed in rats is piperazine-N-oxide (M5), its concentrations in human plasma are low. On the other hand, the most frequent metabolites in monkeys and humans are M20 and M24, the products of hydroxylation. In spite of the fact that all of these compounds hold certain activity, they don't significantly contribute to total dasatinib efficacy, due to their low potency (Christopher et al., 2008a, b).

The bile of duct cannulated rats contains mainly $\mathrm{N}$-oxides and conjugates, while dasatinib and oxidative metabolites other than $\mathrm{N}$-oxides are found in faeces of intact rats. That can be caused by a hydrolysis of conjugates and a reduction of $\mathrm{N}$-oxides by microorganisms in the course of passage through gastrointestinal tract before being excreted (Christopher et al., 2008a).

When various metabolism of dasatinib via CYP enzymes or flavin-containing monooxygenase 3 (FMO3) were tested in vitro, it turned out that all of them are able to metabolize dasatinib with CYP3A4 showing to be the most potent enzyme (Kamath et al., 2008).

Dasatinib exposure was increased when coadministred with ketoconazole in man (Johnson et al., 2010). Conversely, rifampicin, a CYP3A4 inducer, led to a decrease in dasatinib exposure, confirming that dasatinib is a CYP3A4 substrate (Bristol-Myers Squibb, 2017). Therefore, it is recommended to avoid simultaneous administration with strong CYP3A4 inhibitors or inducers such as grapefruit juice because of possible drug interactions. If necessary, dasatinib doses can be modified in order to maintain adequate plasma concentrations. Concomitant administration with other CYP3A4 substrates should be employed with caution as dasatinib itself acts as a CYP3A4 inhibitor (Bristol-Myers Squibb, 2006).

Dasatinib is mainly excreted in the form of metabolites, as only 15 to $19 \%$ remains unchanged. The excretion occurs into faeces (particularly bile), the amount of drug being excreted in urine is very low (Christopher et al., 2008a, b; Kamath et al., 2008).

Impact of drug transporters

The role of dasatinib transport through cell membranes has been investigated in order to map possible influence of some efflux proteins and transporters on dasatinib distribution. Unlike imatinib, dasatinib cell uptake isn't dependent on the activity of human organic cation transporter 1 (hOCT1) (Giannoudis et al., 2008; Hiwase et al., 2008). This transporter was found to be important for imatinib active transport into cells and its lower expression can contribute to treatment resistance (Thomas et al., 2004).

ATP-binding cassette transporters ( $A B C$ transporters) have major importance on dasatinib influx/efflux. For example, ABCC4 participates in its gastric absorption 
(Furmanski et al., 2013). There are other important transporters belonging to this family, like ABCB1 (P-glycoprotein - P-gP) and ABCG2 (breast cancer resistance protein - BCRP). Those proteins are expressed at various barriers, such as intestinal epithelium and blood-brain barrier or blood-testis barrier, where they are able to transport endogenous substances as well as xenobiotics through membranes. Sometimes, their efflux function can cause drug resistance as they prevent the drug to reach its intracellular target (Borst and Elferink, 2002).

Dasatinib may be transported by both of these proteins (Giannoudis et al., 2008; Hiwase et al., 2008; Chen et al., 2009; Hegedus et al., 2009). First findings comparing wild-type and P-gp knockout mice suggested that although dasatinib is a P-gp substrate, it doesn't contribute to low bioavailability (Kamath et al., 2008). Nevertheless, later investigations brought results saying that P-gP can limit dasatinib absorption after oral administration (Lagas et al., 2009). The importance of both transporters (P-gP and BCRP) is supported by results of a study with double knocked-out rats for P-gP and BCRP, which had two-fold higher dasatinib AUC compared with wild-type rats (Tang et al., 2013). Dasatinib can also act as an inhibitor of both of these proteins in higher concentrations and thus it could influence transport of another substances (Hegedus et al., 2009). Nevertheless, the practical impact of those findings on a clinical use in patients with CML has not yet been reliably elucidated.

P-gp also plays a major role in restricting dasatinib accumulation in central nervous system. Although absence of BCRP didn't affect dasatinib brain concentration, inhibition of both these transporters together resulted in considerably higher brain concentration compared to inhibition of only P-gP (Chen et al., 2009; Lagas et al., 2009; Tang et al., 2013). Possible explanations are that P-gp might be able to compensate BCRP loss, or that BCRP can partly take over P-gp's function in its absence.

Pharmacokinetics in special populations

Pharmacokinetic properties of dasatinib were also studied in paediatric settings. Overally, the pharmacokinetics is very similar to that observed in adults and there were no substantial differences. The doses should be reduced and adjusted by body weight or by occurred adverse reactions (Aplenc et al., 2011; Bristol-Myers Squibb, 2017).

Although dasatinib is metabolised through liver, it is not recommended to reduce the dose in patients with mild to moderate hepatic dysfunction (Bristol-Myers Squibb, 2006; Sasaki et al., 2016).

\section{Relationship of pharmacokinetics and pharmacodynamics}

Dasatinib exhibits time-dependent effect where plasma concentrations above inhibitory concentration ( $\left(\mathrm{C} 55_{\mathrm{CD} 34+\text { cells }}\right)$ for more than $12.8 \mathrm{~h}$ led to a better clinical response (Ishida et al., 2016). Dasatinib shows many adverse effects like 
thrombocytopenia, neutropenia, leucopenia, anaemia, asthenia, pleural effusion, fatigue, nausea or diarrhoea (Visani et al., 2010). The toxicity increases with higher plasma concentrations and so it can be useful to monitor plasma levels of dasatinib in patients in order to prevent serious side effects, particularly in patients with decreased clearance (Demetri et al., 2009).

\section{Conclusion}

Dasatinib is a drug with an important role in the management of CML. Its absorption is strongly dependent on gastric $\mathrm{pH}$ as it only dissolves at low $\mathrm{pH}$ values. For that reason, it is important to pay attention to concomitant use of medications that could modulate gastric $\mathrm{pH}$ (e.g. antacids, $\mathrm{H}_{2}$-receptor antagonists, proton pump inhibitors). After being absorbed into circulatory system, dasatinib binds to plasma proteins to a high degree and it is well distributed to the organs as well as to the breast milk of lactating females. Before being excreted mostly by faeces, dasatinib undergoes predominantly oxidative metabolism mediated by cytochrome P450 and inhibitors or inducers of this enzymatic system can alter dasatinib pharmacokinetics.

\section{References}

Aplenc, R., Blaney, S. M., Strauss, L. C., Balis, F. M., Shusterman, S., Ingle, A. M., Agrawal, S., Sun, J., Wright, J. J., Adamson, P. C. (2011) Pediatric phase I trial and pharmacokinetic study of dasatinib: A report from the children's oncology group phase I consortium. J. Clin. Oncol. 29, 839-844.

AstraZeneca Pharmaceuticals (2012) Prilosec - Full prescribing information. Available at: https:// www.accessdata.fda.gov/drugsatfda_docs/label/2012/019810s096lbl.pdf

Borst, P., Elferink, R. O. (2002) Mammalian ABC transporters in health and disease. Annu. Rev. Biochem. 71, 537-592.

Bristol-Myers Squibb (2006) Sprycel: Summary of product characteristics. Available at: https://www.ema. europa.eu/en/documents/product-information/sprycel-epar-product-information_en.pdf

Bristol-Myers Squibb (2017) Sprycel: Full prescribing information. Available at: https://packageinserts.bms. com/pi/pi_sprycel.pdf

Bristol-Myers Squibb Pharmaceutical Research Institute (2007) Investigator brochure: Dasatinib (BMS-354825). Available at: http://spirit-cml.org/isf/referencesafetyinformation/1.2\%20Dasatinib\%20RSI\%20-\%20 Dasatinib\%20lB\%20(Nov07)\%20superseded.pdf

Chandani, R., He, J., Trabelsi, F. (2017) Atypical pharmacokinetic profiles observed with dasatinib reference listed drug product in bioequivalence studies. Presented at the AAPS Annual Meeting, San Diego.

Available at: https://www.biopharmaservices.com/wp-content/uploads/2018/06/Poster-1-Dasatinib -final-AAPS-2017.pdf

Chen, Y., Agarwal, S., Shaik, N. M., Chen, C., Yang, Z., Elmquist, W. F. (2009) P-glycoprotein and breast cancer resistance protein influence brain distribution of dasatinib. J. Pharmacol. Exp. Ther. 330, 956-963.

Christopher, L. J., Cui, D., Li, W., Barros, A. Jr., Arora, V. K., Zhang, H., Wang, L., Zhang, D., Manning, J. A., He, K., Fletcher, A. M., Ogan, M., Lago, M., Bonacorsi, S. J., Humphreys, W. G., lyer, R. A. (2008a) Biotransformation of [14C]dasatinib: in vitro studies in rat, monkey, and human and disposition after administration to rats and monkeys. Drug Metab. Dispos. 36, 1341-1356.

Christopher, L. J., Cui, D., Wu, C., Luo, R., Manning, J. A., Bonacorsi, S. J., Lago, M., Allentoff, A., Lee, F. Y., McCann, B., Galbraith, S., Reitberg, D. P., He, K., Barros, A. Jr., Blackwood-Chirchir, A., 
Humphreys, W. G., lyer, R. A. (2008b) Metabolism and disposition of dasatinib after oral administration to humans. Drug Metab. Dispos. 36, 1357-1364.

Chu, S., Tanaka, S., Kaunitz, J. D., Montrose, M. H. (1999) Dynamic regulation of gastric surface $\mathrm{pH}$ by luminal pH. J. Clin. Invest. 103, 605-612.

Cohen, P. (2002) Protein kinases - The major drug targets of the twenty-first century? Nat. Rev. Drug Discov. 1, 309-315.

Dai, G., Pfister, M., Blackwood-Chirchir, A., Roy, A. (2008) Importance of characterizing determinants of variability in exposure: Application to dasatinib in subjects with chronic myeloid leukemia. J. Clin. Pharmacol. 48, 1254-1269.

Demetri, G. D., Lo Russo, P., MacPherson, I. R., Wang, D., Morgan, J. A., Brunton, V. G., Paliwal, P., Agrawal, S., Voi, M., Evans, T. R. (2009) Phase I dose-escalation and pharmacokinetic study of dasatinib in patients with advanced solid tumors. Clin. Cancer Res. 15, 6232-6240.

Eley, T., Luo, F. R., Agrawal, S., Sanil, A., Manning, J., Li, T., Blackwood-Chirchir, A., Bertz, R. (2009) Phase I study of the effect of gastric acid $\mathrm{pH}$ modulators on the bioavailability of oral dasatinib in healthy subjects. J. Clin. Pharmacol. 49, 700-709.

Furmanski, B. D., Hu, S., Fujita, K. I., Li, L., Gibson, A. A., Janke, L. J., Williams, R. T., Schuetz, J. D., Sparreboom, A., Baker, S. D. (2013) Contribution of ABCC4-mediated gastric transport to the absorption and efficacy of dasatinib. Clin. Cancer Res. 19, 4359-4370.

Giannoudis, A., Davies, A., Lucas, C. M., Harris, R. J., Pirmohamed, M., Clark, R. E. (2008) Effective dasatinib uptake may occur without human organic cation transporter 1 (hOCT1): Implications for the treatment of imatinib-resistant chronic myeloid leukemia. Blood 112, 3348-3354.

He, K., Lago, M. W., lyer, R. A., Shyu, W. C., Humphreys, W. G., Christopher, L. J. (2008) Lacteal secretion, fetal and maternal tissue distribution of dasatinib in rats. Drug Metab. Dispos. 36, 2564-2570.

Hegedus, C., Ozvegy-Laczka, C., Apati, A., Magocsi, M., Nemet, K., Orfi, L., Keri, G., Katona, M., Takats, Z., Varadi, A., Szakacs, G., Sarkadi, B. (2009) Interaction of nilotinib, dasatinib and bosutinib with ABCB1 and ABCG2: Implications for altered anti-cancer effects and pharmacological properties. Br. J. Pharmacol. 158, 1153-1164.

Hiwase, D. K., Saunders, V., Hewett, D., Frede, A., Zrim, S., Dang, P., Eadie, L., To, L. B., Melo, J., Kumar, S., Hughes, T. P., White, D. L. (2008) Dasatinib cellular uptake and efflux in chronic myeloid leukemia cells: therapeutic implications. Clin. Cancer Res. 14, 3881-3888.

Ikeda, H., Kanakura, Y., Tamaki, T., Kuriu, A., Kitayama, H., Ishikawa, J., Kanayama, Y., Yonezawa, T., Tarui, S., Griffin, J. D. (1991) Expression and functional role of the proto-oncogene c-kit in acute myeloblastic leukemia cells. Blood 78, 2962-2968.

Ishida, Y., Murai, K., Yamaguchi, K., Miyagishima, T., Shindo, M., Ogawa, K., Nagashima, T., Sato, S., Watanabe, R., Yamamoto, S., Hirose, T., Saitou, S., Yonezumi, M., Kondo, T., Kato, Y., Mochizuki, N., Ohno, K., Kishino, S., Kubo, K., Oyake, T., Ito, S. (2016) Pharmacokinetics and pharmacodynamics of dasatinib in the chronic phase of newly diagnosed chronic myeloid leukemia. Eur. J. Clin. Pharmacol. 72, 185-193.

Johnson, F. M., Agrawal, S., Burris, H., Rosen, L., Dhillon, N., Hong, D., Blackwood-Chirchir, A., Luo, F. R., Sy, O., Kaul, S., Chiappori, A. A. (2010) Phase 1 pharmacokinetic and drug-interaction study of dasatinib in patients with advanced solid tumors. Cancer 116, 1582-1591.

Kamath, A. V., Wang, J., Lee, F. Y., Marathe, P. H. (2008) Preclinical pharmacokinetics and in vitro metabolism of dasatinib (BMS-354825): A potent oral multi-targeted kinase inhibitor against SRC and BCR-ABL. Cancer Chemother. Pharmacol. 61, 365-376.

Lagas, J. S., van Waterschoot, R. A., van Tilburg, V. A., Hillebrand, M. J., Lankheet, N., Rosing, H., Beijnen, J. H., Schinkel, A. H. (2009) Brain accumulation of dasatinib is restricted by P-glycoprotein 
(ABCB1) and breast cancer resistance protein (ABCG2) and can be enhanced by elacridar treatment. Clin. Cancer Res. 15, 2344-2351.

Liu, F., Lang, L. W., Jiang, J., Lu, H. J., Wang, J. M., Wang, S. C. (2013) Synthesis and biopharmaceutical studies of JLTN as potential dasatinib prodrug. Chem. Pharm. Bull. (Tokyo) 61, 877-881.

Lombardo, L. J., Lee, F. Y., Chen, P., Norris, D., Barrish, J. C., Behnia, K., Castaneda, S., Cornelius, L. A., Das, J., Doweyko, A. M., Fairchild, C., Hunt, J. T., Inigo, I., Johnston, K., Kamath, A., Kan, D., Klei, H., Marathe, P., Pang, S., Peterson, R., Pitt, S., Schieven, G. L., Schmidt, R. J., Tokarski, J., Wen, M. L., Wityak, J., Borzilleri, R. M. (2004) Discovery of N-(2-chloro-6-methyl-phenyl)-2-(6-(4-(2-hydroxyethyl) -piperazin-1-yl)-2-methylpyrimidin-4-ylamino)thiazole-5-carboxamide (BMS-354825), a dual Src/Abl kinase inhibitor with potent antitumor activity in preclinical assays. J. Med. Chem. 47, 6658-6661.

Lubach, J. W., Chen, J. Z., Hau, J., Imperio, J., Coraggio, M., Liu, L., Wong, H. (2013) Investigation of the rat model for preclinical evaluation of $\mathrm{pH}$-dependent oral absorption in humans. Mol. Pharm. 10, 3997-4004.

Luo, F. R., Yang, Z., Camuso, A., Smykla, R., McGlinchey, K., Fager, K., Flefleh, C., Castaneda, S., Inigo, I., Kan, D., Wen, M. L., Kramer, R., Blackwood-Chirchir, A., Lee, F. Y. (2006) Dasatinib (BMS-354825) pharmacokinetics and pharmacodynamic biomarkers in animal models predict optimal clinical exposure. Clin. Cancer Res. 12, 7180-7186.

Matsuoka, A., Takahashi, N., Miura, M., Niioka, T., Kawakami, K., Matsunaga, T., Sawada, K. (2012) $\mathrm{H} 2$-receptor antagonist influences dasatinib pharmacokinetics in a patient with Philadelphia-positive acute lymphoblastic leukemia. Cancer Chemother. Pharmacol. 70, 351-352.

Minematsu, T., Giacomini, K. M. (2011) Interactions of tyrosine kinase inhibitors with organic cation transporters and multidrug and toxic compound extrusion proteins. Mol. Cancer Ther. 10, 531-539.

Mylan Pharmaceuticals (2011) Mylan-famotidine - Product monograph. Available at: https://pdf.hres.ca /dpd_pm/00014548.PDF

Novartis (2018) Gleevec: Full prescribing information. Available at: https://www.pharma.us.novartis.com /sites/www.pharma.us.novartis.com/files/gleevec_tabs.pdf

O'Hare, T., Walters, D. K., Stoffregen, E. P., Jia, T., Manley, P. W., Mestan, J., Cowan-Jacob, S. W., Lee, F. Y., Heinrich, M. C., Deininger, M. W., Druker, B. J. (2005) In vitro activity of Bcr-Abl inhibitors AMN107 and BMS-354825 against clinically relevant imatinib-resistant Abl kinase domain mutants. Cancer Res. 65, 4500-4505.

Pali-Scholl, I., Herzog, R., Wallmann, J., Szalai, K., Brunner, R., Lukschal, A., Karagiannis, P., Diesner, S. C., Jensen-Jarolim, E. (2010) Antacids and dietary supplements with an influence on the gastric $\mathrm{pH}$ increase the risk for food sensitization. Clin. Exp. Allergy 40, 1091-1098.

Pang, J., Dalziel, G., Dean, B., Ware, J. A., Salphati, L. (2013) Pharmacokinetics and absorption of the anticancer agents dasatinib and GDC-0941 under various gastric conditions in dogs - Reversing the effect of elevated gastric $\mathrm{pH}$ with betaine $\mathrm{HCl}$. Mol. Pharm. 10, 4024-4031.

Sasaki, K., Lahoti, A., Jabbour, E., Jain, P., Pierce, S., Borthakur, G., Daver, N., Kadia, T., Pemmaraju, N., Ferrajoli, A., O’Brien, S., Kantarjian, H., Cortes, J. (2016) Clinical safety and efficacy of nilotinib or dasatinib in patients with newly diagnosed chronic-phase chronic myelogenous leukemia and pre-existing liver and/or renal dysfunction. Clin. Lymphoma Myeloma Leuk. 16, 152-162.

Shah, N. P., Tran, C., Lee, F. Y., Chen, P., Norris, D., Sawyers, C. L. (2004) Overriding imatinib resistance with a novel ABL kinase inhibitor. Science 305, 399-401.

Šíma, M., Kutinová-Canová, N., Ryšánek, P., Hořínková, J., Moškořová, D., Slanař, O. (2019) Gastric pH in rats: Key determinant for preclinical evaluation of pH-dependent oral drug absorption. Prague Med. Rep. 120, $5-9$. 
Szczylik, C., Skorski, T., Nicolaides, N. C., Manzella, L., Malaguarnera, L., Venturelli, D., Gewirtz, A. M., Calabretta, B. (1991) Selective inhibition of leukemia cell proliferation by BCR-ABL antisense oligodeoxynucleotides. Science 253, 562-565.

Takahashi, N., Miura, M., Niioka, T., Sawada, K. (2012) Influence of H2-receptor antagonists and proton pump inhibitors on dasatinib pharmacokinetics in Japanese leukemia patients. Cancer Chemother. Pharmacol. 69, 999-1004.

Takahashi, S., Miyazaki, M., Okamoto, I., Ito, Y., Ueda, K., Seriu, T., Nakagawa, K., Hatake, K. (2011) Phase I study of dasatinib (BMS-354825) in Japanese patients with solid tumors. Cancer Sci. 102, 2058-2064.

Tang, S. C., de Vries, N., Sparidans, R. W., Wagenaar, E., Beijnen, J. H., Schinkel, A. H. (2013) Impact of P-glycoprotein (ABCB1) and breast cancer resistance protein (ABCG2) gene dosage on plasma pharmacokinetics and brain accumulation of dasatinib, sorafenib, and sunitinib. J. Pharmacol. Exp. Ther.

346, 486-494.

Thomas, J., Wang, L., Clark, R. E., Pirmohamed, M. (2004) Active transport of imatinib into and out of cells: implications for drug resistance. Blood 104, 3739-3745.

Thomas, S. M., Brugge, J. S. (1997) Cellular functions regulated by Src family kinases. Annu. Rev. Cell Dev. Biol. 13, 513-609.

Visani, G., Breccia, M., Gozzini, A., Specchia, G., Montefusco, E., Morra, E., Annunziata, M., Camera, A., Cavazzini, F., Stagno, F., Pregno, P., Usala, E., Santini, V., Piccaluga, P. P., Isidori, A. (2010) Dasatinib, even at low doses, is an effective second-line therapy for chronic myeloid leukemia patients resistant or intolerant to imatinib. Results from a real life-based Italian multicenter retrospective study on 114 patients. Am. J. Hematol. 85, 960-963.

Yago, M. R., Frymoyer, A. R., Smelick, G. S., Frassetto, L. A., Budha, N. R., Dresser, M. J., Ware, J. A., Benet, L. Z. (2013) Gastric reacidification with betaine $\mathrm{HCl}$ in healthy volunteers with rabeprazole-induced hypochlorhydria. Mol. Pharm. 10, 4032-4037.

Yago, M. R., Frymoyer, A., Benet, L. Z., Smelick, G. S., Frassetto, L. A., Ding, X., Dean, B., Salphati, L., Budha, N., Jin, J. Y., Dresser, M. J., Ware, J. A. (2014) The use of betaine $\mathrm{HCl}$ to enhance dasatinib absorption in healthy volunteers with rabeprazole-induced hypochlorhydria. AAPS J. 16, 1358-1365.

Yang, J., Liu, X., Nyland, S. B., Zhang, R., Ryland, L. K., Broeg, K., Baab, K. T., Jarbadan, N. R., Irby, R., Loughran, T. P. Jr. (2010) Platelet-derived growth factor mediates survival of leukemic large granular lymphocytes via an autocrine regulatory pathway. Blood 115, 51-60. 